\title{
Angucycline Glycosides from an Intertidal Sediments Strain Streptomyces sp. and Their Cytotoxic Activity against Hepatoma Carcinoma Cells
}

\author{
Aihong Peng ${ }^{1,2}$, Xinying Qu ${ }^{1}$, Fangyuan Liu ${ }^{1}, \mathrm{Xia} \mathrm{Li}^{1}$, Erwei Li ${ }^{2, *}$ and Weidong Xie ${ }^{1, *(D)}$ \\ 1 Department of Pharmacy, College of Marine Science, Shandong University, Weihai 264209, China; \\ pengahsdu@163.com (A.P.); quxinying321@163.com (X.Q.); fangyuan617@outlook.com (F.L.); \\ xiali@sdu.edu.cn (X.L.) \\ 2 State Key Laboratory of Mycology, Institute of Microbiology, Chinese Academy of Sciences, \\ Beijing 100101, China \\ * Correspondence: liew@im.ac.cn (E.L.); wdxie@sdu.edu.cn (W.X.); Tel.: +86-10-6480-6141 (E.L.); \\ $+86-631-568-8303$ (W.X.)
}

Received: 4 November 2018; Accepted: 25 November 2018; Published: 27 November 2018

\begin{abstract}
Four angucycline glycosides including three new compounds landomycin $N(1)$, galtamycin C (2) and vineomycin D (3), and a known homologue saquayamycin B (4), along with two alkaloids 1-acetyl- $\beta$-carboline (5) and indole-3-acetic acid (6), were isolated from the fermentation broth of an intertidal sediments-derived Streptomyces sp. Their structures were established by IR, HR-ESI-MS, 1D and 2D NMR techniques. Among the isolated angucyclines, saquayamycin B (4) displayed potent cytotoxic activity against hepatoma carcinoma cells HepG-2, SMMC-7721 and plc-prf-5, with $\mathrm{IC}_{50}$ values $0.135,0.033$ and $0.244 \mu \mathrm{M}$ respectively, superior to doxorubicin. Saquayamycin B (4) also induced apoptosis in SMMC-7721 cells as detected by its morphological characteristics in 4',6-diamidino-2-phenylindole (DAPI) staining experiment.
\end{abstract}

Keywords: Streptomyces; angucycline glycosides; saquayamycin; cytotoxicity; apoptosis; SMMC-7721

\section{Introduction}

Angucycline is a group of aromatic polyketides containing a benz[a]anthraquinone framework of the aglycone which is mostly attached with C-glycosidic moiety [1]. Naturally occurring angucyclines are exclusively produced by terrestrial and marine actinomycetes, especially Streptomycetes species, in which a decaketide initially derived from acetyl-CoA is catalytically cyclized to four-ring core of angucycline by polyketide cyclase [2]. The structures of angucycline glycosides always vary in the oxidation degree of aglycones along with the number and position of diverse deoxy sugars [1-4]. In some cases, e.g., galtamycin B [5], grincamycin B [6], and vineomycin $B_{2}$ [7], the angular four-ring of typical angucycline is rearranged to linear tetracyclic or tricyclic system by enzymatic or non-enzymatic modification. Although firstly discovered half a century ago and possessing potent antibacterial, antiproliferative, and cytotoxic activities [6-11], so far, none of angucycline compounds has been successfully developed into clinical drug due to toxicity or solubility issues, which is unlike their biogenetic relatives tetracycline and anthracycline antibiotics [2]. Recent researches on angucyclines mainly concentrated on the understanding of their biosynthetic pathways in order to obtain modified analogues with medicinal potentiality through genetic manipulation [12-14].

Intertidal ecosystems are significantly different from those of seafloor. Regular tide immersion and emersion result in the dissolution of more organic carbon as well as oxygen and sulfate into intertidal sediment, which is beneficial to microbes' survival, particularly to aerobic actinomycetes. Both metagenomes and culture-dependent isolation have verified the abundance and diversity of 
Actinobacteria in intertidal sediment [15]. Thus, we exploited the Actinobacteria resources from the intertidal sediment of Xiaoshi Island in Weihai, China, to screen for new antitumor agents. As a result, a Streptomyces sp., designated OC1610.4, was obtained, and its 16S rRNA nucleotide sequence (Accession no. MK045847) shared only $81.8 \%$ and $81.6 \%$ similarity, respectively, with those of Streptomyces chromofuscus (FJ486284) and Streptomyces lannensis (KM370050) in GenBank. The thin layer chromatography (TLC) analysis of its EtOAc extract of liquid culture medium displayed several yellow and brown spots, presumably due to aromatic polyketides. Subsequent large-scale fermentation and chromatographic isolation led to the identification of four angucycline glycosides including three new compounds, namely landomycin N (1), galtamycin C (2) and vineomycin D (3), and the previously reported saquayamycin B (4) (Figure 1), along with two alkaloids 1 -acetyl- $\beta$-carboline (5) and indole-3-acetic acid (6) $[16,17]$. Saquayamycin B (4) displayed potent cytotoxic activity against hepatoma carcinoma HepG-2, SMMC-7721 and plc-prf-5 cell lines, and it caused apoptosis in SMMC-7721 cells.<smiles>[R]c1ccc2c(=O)c3c(cc(O)c4cc(C)cc(O)c43)[Z7](=O)c2c1O</smiles>

1<smiles>[R]c1ccc2c(c1O)C(=O)C1=CC=CC3(O)C(C(=O)CC(C)(O)C[C@@]3([R20])O)C12</smiles>

$\mathrm{R}_{1}$

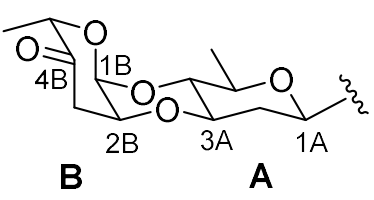<smiles>[R3]c1ccc2c(c1O)C(=O)c1cc3c(O)cc(C)cc3c(O)c1C2=O</smiles>

2<smiles>CC(=O)c1nccc2c1[nH]c1ccccc12</smiles>

$\mathrm{R}_{2}$

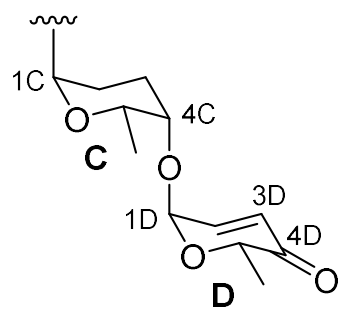<smiles>[R]c1ccc2c(c1O)C(=O)c1ccc(CC([Y9])([R20])CC(=O)O)c(O)c1C2=O</smiles>

3

Figure 1. Structures of 1-6.

\section{Results and Discussion}

From 30 L liquid fermentation broth of the strain Streptomyces sp. OC1610.4, cultured for 9 days, $4.6 \mathrm{~g}$ of EtOAc extract was obtained. After fractionation by column chromatography and preparative HPLC purification, six yellow or brown amorphous powdered-compounds were isolated from the crude EtOAc extract. The major constituent in the extract was firstly purified and whose molecular formula $\mathrm{C}_{43} \mathrm{H}_{48} \mathrm{O}_{16}$ was established by the HR-ESI-MS $m / z 838.3298$ ([M $\left.+\mathrm{NH}_{4}\right]^{+}$, calcd for $\left.\mathrm{C}_{43} \mathrm{H}_{52} \mathrm{NO}_{16}, 838.3286\right)$ and $m / z$ 843.2842 ([M + Na $]^{+}$, calcd for $\mathrm{C}_{43} \mathrm{H}_{48} \mathrm{NaO}_{16}, 843.2840$ ) (Figure S1). Its ${ }^{1} \mathrm{H}$ NMR spectrum displayed complex signals including three pairs of aromatic or olefinic protons from $\delta_{\mathrm{H}} 6.06$ to 7.91 , more than a dozen methylene and methine protons from $\delta_{\mathrm{H}} 1.40$ to 5.39 and five methyl groups (Figure S2). The four oxygenated methine proton signals between $\delta_{\mathrm{H}} 5.01$ and 5.40 which, through HSQC spectrum, directly attached to the carbons signals at $\delta_{C} 96.0,92.8,92.1$ and 
72.0 (Figure S3), along with four doublets of methyl groups are the characteristic of four deoxy sugar molecules, one of which probably formed a C-glycoside since its anomeric carbon appeared at $\delta_{C}$ $72.0[18,19]$. These data, especially the signals of the deoxy sugar C-glycosidic moiety suggested the structure of angucycline glycoside [1]. Detailed comparison of its ${ }^{1} \mathrm{H}$ and ${ }^{13} \mathrm{C}$ NMR data with those previously reported in the literature and analysis of the 2D NMR sprectra (Figures S5-S8), led to the identification of this compound as saquayamycin B $(4)[3,18]$.

Landomycin $\mathrm{N}(\mathbf{1})$ was a minor constituent of the crude extract. Its molecular formula $\mathrm{C}_{31} \mathrm{H}_{28} \mathrm{O}_{10}$ was established by the $m / z 561.1753\left([\mathrm{M}+\mathrm{H}]^{+}\right.$, calcd for $\left.\mathrm{C}_{31} \mathrm{H}_{29} \mathrm{O}_{10}, 561.1761\right)$ from HR-ESI-MS. The IR spectrum showed the absorption band of hydroxyl $\left(3203 \mathrm{~cm}^{-1}\right)$, carbonyl $\left(1726,1629 \mathrm{~cm}^{-1}\right)$ and aromatic $\left(1607,1578 \mathrm{~cm}^{-1}\right)$ groups. The ${ }^{1} \mathrm{H}$ and ${ }^{13} \mathrm{C}$ NMR, in combination with APT and HMQC spectra (Figures S11 and S12), revealed the presence of five aromatic protons, seven oxygenated methines, two methylenes and three methyl groups (Table 1). The five aromatic protons at $\delta_{\mathrm{H}} 7.84(\mathrm{~d}$, $J=7.9 \mathrm{~Hz}), 7.72(\mathrm{~d}, J=7.9 \mathrm{~Hz}), 7.62(\mathrm{brs}), 7.46(\mathrm{~s})$ and $6.96(\mathrm{brs})$, similar to those of urdamycin N4 [4], were assigned to the benz[a]anthraquinone nucleus of angucycline aglycone. The COSY spectrum exhibited the correlations from $\delta_{\mathrm{H}} 7.84(\mathrm{H}-10)$ to $\delta_{\mathrm{H}} 7.72(\mathrm{H}-11)$ and from $\delta_{\mathrm{H}} 7.62(\mathrm{H}-2)$ to $\delta_{\mathrm{H}} 6.96$ (H-4) (Figure 2 and Figure S14). The HMBC correlations from $\delta_{\mathrm{H}} 7.84(\mathrm{H}-10)$ to $\mathrm{C}-8\left(\delta_{\mathrm{C}} 156.9\right)$ and C-11a $\left(\delta_{C} 134.7\right), \delta_{H} 7.72(\mathrm{H}-11)$ to $C-7 a\left(\delta_{C} 114.1\right), C-9\left(\delta_{C} 135.0\right)$ and $C-12\left(\delta_{C} 182.6\right)$, and $\delta_{H} 7.46$ $(\mathrm{H}-6)$ to $\mathrm{C}-4 \mathrm{a}\left(\delta_{\mathrm{C}} 130.6\right), \mathrm{C}-7\left(\delta_{\mathrm{C}} 188.9\right)$ and $\mathrm{C}-12 \mathrm{a}\left(\delta_{\mathrm{C}} 119.6\right)$ supported the presence of anthraquinone nucleus of angucycline aglycone. Although C-12 signal was not observed in the ${ }^{13} \mathrm{C}$ NMR spectrum, its chemical shift value was assigned as $\delta_{\mathrm{C}} 182.6$ through the correlation from $\mathrm{H}-11$ to this signal in the $\mathrm{HMBC}$ spectrum. The presence of the hydroxyl substituent on C-8 on the anthraquinone nucleus was supported by the HMBC correlations from H-10 $\left(\delta_{\mathrm{H}} 7.84\right)$ to C-8 $\left(\delta_{\mathrm{C}} 156.9\right)$, and $8-\mathrm{OH}\left(\delta_{\mathrm{H}} 12.53\right)$ to C-7a $\left(\delta_{C} 114.1\right), C-8\left(\delta_{C} 156.9\right)$ and $C-9\left(\delta_{C} 135.0\right)$. The HMBC correlations from $\mathrm{CH}_{3}\left(\delta_{\mathrm{H}} 2.40\right)$ to $\mathrm{C}-2$ $\left(\delta_{C} 119.4\right), C-3\left(\delta_{C} 139.0\right), C-4\left(\delta_{C} 114.2\right), H-2\left(\delta_{H} 6.96\right)$ to $C-1\left(\delta_{C} 155.4\right), C-4\left(\delta_{C} 114.2\right)$ and C-12b $\left(\delta_{C}\right.$ $122.1)$, and $\mathrm{H}-4\left(\delta_{\mathrm{H}} 7.62\right)$ to $C-2\left(\delta_{C} 119.4\right), C-4 a\left(\delta_{C} 130.6\right)$ and $C-12 b\left(\delta_{C} 122.1\right)$ confirmed the structure of the fourth ring conjugated to anthraquinone nucleus and the attachment of hydroxyl group at $\mathrm{C}-1$ $\left(\delta_{C} 155.4\right)$ (Figure 2$)$. The chemical shift of $C-5\left(\delta_{C} 166.4\right)$ along with the HMBC correlation from H-4 $\left(\delta_{\mathrm{H}} 7.26\right)$ to $\mathrm{C}-5$ suggested the presence of the hydroxyl group at $\mathrm{C}-5$.

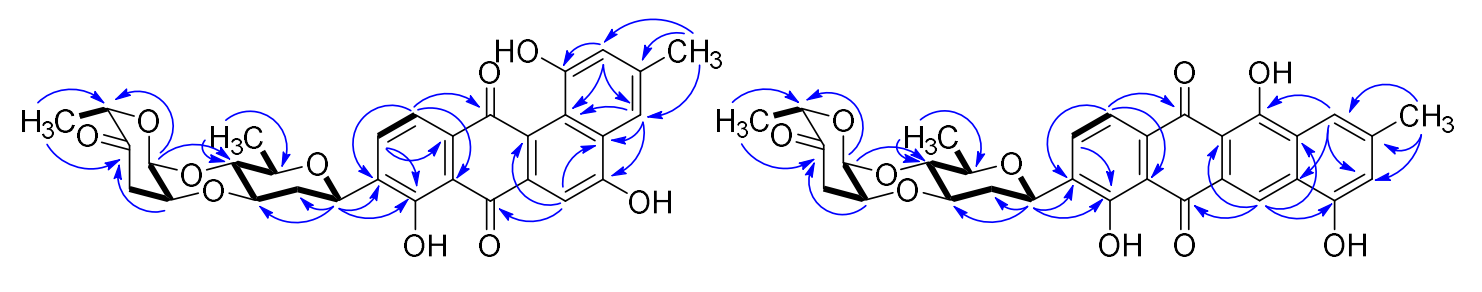

1

2

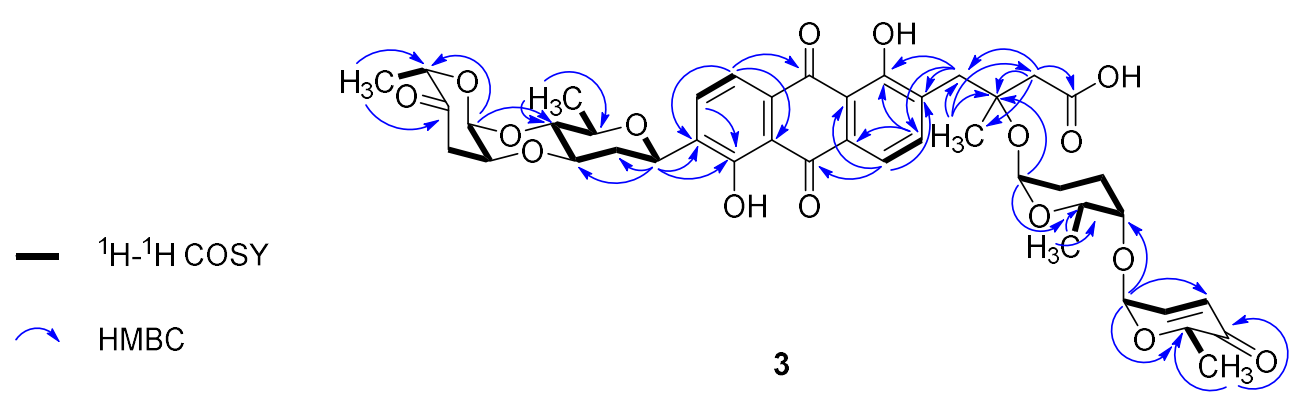

Figure 2. COSY and selected HMBC correlations for 1-3. 
Table 1. The ${ }^{1} \mathrm{H}$ and ${ }^{13} \mathrm{C}$ NMR data of $\mathbf{1}-\mathbf{3}(500 \mathrm{MHz}$ and $125 \mathrm{MHz}){ }^{\mathrm{a}}$.

\begin{tabular}{|c|c|c|c|c|c|c|}
\hline No. & & $1^{b}$ & & $2^{b}$ & & $3^{c}$ \\
\hline & $\delta \mathrm{C}$ type & $\delta \mathrm{H}$, mult $(J$ in $\mathrm{Hz})$ & $\delta \mathrm{C}$ type & $\delta \mathrm{H}$, mult $(J$ in $\mathrm{Hz})$ & $\delta C$ type & $\delta \mathrm{H}$, mult $(J$ in $\mathrm{Hz})$ \\
\hline 1 & $155.4 \mathrm{C}$ & - & $155.9 \mathrm{C}$ & - & $172.1 \mathrm{C}$ & - \\
\hline 2 & $119.4 \mathrm{CH}$ & 6.96, brs & $116.2 \mathrm{CH}$ & 6.95, brs & $44.6 \mathrm{CH}_{2}$ & $\begin{array}{l}2.63, \mathrm{~d}(15.0) \\
2.72, \mathrm{~d}(15.0)\end{array}$ \\
\hline 3 & $139.0 \mathrm{C}$ & - & $141.8 \mathrm{C}$ & - & $78.0 \mathrm{C}$ & - \\
\hline 4 & $114.2 \mathrm{CH}$ & 7.26, brs & $114.2 \mathrm{CH}$ & 7.52, brs & $39.0 \mathrm{CH}_{2}$ & $\begin{array}{l}\text { 3.19, d (13.4) } \\
3.23, \mathrm{~d}(13.4)\end{array}$ \\
\hline $4 a$ & $130.6 \mathrm{C}$ & - & $128.2 \mathrm{C}$ & - & $136.4 \mathrm{C}$ & - \\
\hline 5 & $166.4 \mathrm{C}$ & - & $124.1 \mathrm{C}$ & - & $140.9 \mathrm{CH}$ & $7.84, \mathrm{~d}(7.8)$ \\
\hline 6 & $106.4 \mathrm{CH}$ & $7.46, \mathrm{~s}$ & $116.7 \mathrm{CH}$ & $8.39, \mathrm{~s}$ & $119.2 \mathrm{CH}$ & $7.75, \mathrm{~d}(7.8)$ \\
\hline $6 a$ & $137.3 \mathrm{C}$ & - & $125.1 \mathrm{C}$ & - & $132.5 \mathrm{C}$ & - \\
\hline 7 & $188.9 \mathrm{C}$ & - & $187.3 \mathrm{C}$ & - & $189.1 \mathrm{C}$ & - \\
\hline $7 a$ & $114.1 \mathrm{C}$ & - & $116.2 \mathrm{C}$ & - & $116.3 \mathrm{C}$ & - \\
\hline 8 & $156.9 \mathrm{C}$ & - & $158.4 \mathrm{C}$ & - & $159.6 \mathrm{C}$ & - \\
\hline 9 & $135.0 \mathrm{C}$ & - & $136.3 \mathrm{C}$ & - & $138.8 \mathrm{C}$ & - \\
\hline 10 & $133.7 \mathrm{CH}$ & $7.84, \mathrm{~d}(7.9)$ & $133.2 \mathrm{CH}$ & $7.87, \mathrm{~d}(7.8)$ & $134.3 \mathrm{CH}$ & $7.94, \mathrm{~d}(7.8)$ \\
\hline 11 & $119.6 \mathrm{CH}$ & $7.72, \mathrm{~d}(7.9)$ & $118.4 \mathrm{CH}$ & $7.73, \mathrm{~d}(7.8)$ & $119.9 \mathrm{CH}$ & $7.80, \mathrm{~d}(7.8)$ \\
\hline $11 \mathrm{a}$ & $134.7 \mathrm{C}$ & - & $132.4 \mathrm{C}$ & - & $133.0 \mathrm{C}$ & - \\
\hline 12 & $182.6 \mathrm{C}$ & - & $186.3 \mathrm{C}$ & - & $189.2 \mathrm{C}$ & - \\
\hline $12 \mathrm{a}$ & $119.6 \mathrm{C}$ & - & $108.8 \mathrm{C}$ & - & $116.4 \mathrm{C}$ & - \\
\hline $12 b$ & $122.1 \mathrm{C}$ & - & $162.1 \mathrm{C}$ & - & $162.4 \mathrm{C}$ & - \\
\hline 13 & $20.9 \mathrm{CH}_{3}$ & $2.40, \mathrm{~s}$ & $21.9 \mathrm{CH}_{3}$ & $2.40, \mathrm{~s}$ & $23.5 \mathrm{CH}_{3}$ & $1.43, \mathrm{~s}$ \\
\hline $\mathrm{OH}$ & - & $12.53, \mathrm{brs}$ & - & $14.40, \mathrm{brs}$ & - & 13.14 , brs \\
\hline $\mathrm{OH}$ & - & 12.08, brs & - & 13.41, brs & - & 13.10 , brs \\
\hline $\mathrm{OH}$ & - & & - & 10.92 , brs & - & \\
\hline \multicolumn{7}{|c|}{ Sugar A, $\beta$-D-olivose } \\
\hline $1 \mathrm{~A}$ & $70.4 \mathrm{CH}$ & 4.97, brd $(10.5)$ & $70.5 \mathrm{CH}$ & 4.96, brd $(10.8)$ & $72.1 \mathrm{CH}$ & 5.01, brd (10.9) \\
\hline $2 \mathrm{~A}$ & $35.9 \mathrm{CH}_{2}$ & $\begin{array}{c}1.63, \text { ddd }(11.6,11.6,10.5) \\
2.22, \mathrm{~m}\end{array}$ & $35.8 \mathrm{CH}_{2}$ & $\begin{array}{c}1.61, \text { ddd }(11.7,11.7,10.8) \\
2.24, \mathrm{~m}\end{array}$ & $37.4 \mathrm{CH}_{2}$ & $\begin{array}{c}1.60, \text { ddd }(11.6,11.6,10.9) \\
2.40, \mathrm{~m}\end{array}$ \\
\hline $3 \mathrm{~A}$ & $75.7 \mathrm{CH}$ & 3.85, ddd $(11.6,9.0,4.4)$ & $75.7 \mathrm{CH}$ & 3.86, ddd $(11.7,9.0,4.3)$ & $77.4 \mathrm{CH}$ & 3.88, ddd $(11.6,8.9,4.4)$ \\
\hline $4 \mathrm{~A}$ & $73.6 \mathrm{CH}$ & $3.51, \mathrm{dd}(9.0,9.0)$ & $73.6 \mathrm{CH}$ & $3.51, \mathrm{dd}(9.0,9.0)$ & $75.1 \mathrm{CH}$ & 3.58, dd $(8.9,8.9)$ \\
\hline $5 \mathrm{~A}$ & $73.5 \mathrm{CH}$ & $3.59, \mathrm{~m}$ & $73.5 \mathrm{CH}$ & $3.60, \mathrm{~m}$ & $75.1 \mathrm{CH}$ & $3.62, \mathrm{~m}$ \\
\hline $6 \mathrm{~A}$ & $17.4 \mathrm{CH}_{3}$ & $1.26, \mathrm{~d}(6.0)$ & $17.4 \mathrm{CH}_{3}$ & $1.27, \mathrm{~d}(6.0)$ & $17.9 \mathrm{CH}_{3}$ & $1.34, \mathrm{~d}(5.8)$ \\
\hline \multicolumn{7}{|c|}{ Sugar B, $\alpha$-L-cinerulose B } \\
\hline 1B & $90.5 \mathrm{CH}$ & $5.22, \mathrm{~d}(2.6)$ & $90.2 \mathrm{CH}$ & $5.23, \mathrm{~d}(2.4)$ & $92.2 \mathrm{CH}$ & $5.26, \mathrm{~d}(2.8)$ \\
\hline $2 \mathrm{~B}$ & $70.8 \mathrm{CH}$ & $4.34, \mathrm{~m}$ & $70.8 \mathrm{CH}$ & $4.35, \mathrm{~m}$ & $72.3 \mathrm{CH}$ & $4.33, \mathrm{~m}$ \\
\hline 3B & $39.6 \mathrm{CH}_{2}$ & $\begin{array}{l}\text { 2.47, dd }(17.4,2.6) \\
2.90, \text { dd }(17.4,2.6)\end{array}$ & $39.8 \mathrm{CH}_{2}$ & $\begin{array}{l}\text { 2.47, dd }(17.3,3.4) \\
2.91, \text { dd }(17.4,2.6)\end{array}$ & $40.6 \mathrm{CH}_{2}$ & $\begin{array}{l}2.53, \text { dd }(17.3,3.6) \\
2.84, \text { dd }(17.3,2.7)\end{array}$ \\
\hline $4 \mathrm{~B}$ & $208.7 \mathrm{C}$ & - & $208.7 \mathrm{C}$ & - & $208.5 \mathrm{C}$ & - \\
\hline $5 B$ & $76.9 \mathrm{CH}$ & $4.72, \mathrm{q}(6.6)$ & $76.9 \mathrm{CH}$ & $4.72, \mathrm{q}(6.6)$ & $78.2 \mathrm{CH}$ & $4.76, \mathrm{q}(6.8)$ \\
\hline $6 \mathrm{~B}$ & $16.0 \mathrm{CH}_{3}$ & $1.24, \mathrm{~d}(6.6)$ & $16.0 \mathrm{CH}_{3}$ & $1.25, \mathrm{~d}(6.6)$ & $16.5 \mathrm{CH}_{3}$ & $1.26, \mathrm{~d}(6.8)$ \\
\hline \multicolumn{7}{|c|}{ Sugar C, $\alpha$-L-rhodinose } \\
\hline $1 \mathrm{C}$ & & & & & $92.0 \mathrm{CH}$ & 5.20, brs \\
\hline $2 \mathrm{C}$ & & & & & $26.2 \mathrm{CH}_{2}$ & $\begin{array}{l}1.40, \mathrm{~m} \\
1.95, \mathrm{~m}\end{array}$ \\
\hline $3 C$ & & & & & $25.3 \mathrm{CH}_{2}$ & $\begin{array}{l}1.90, \mathrm{~m} \\
2.10, \mathrm{~m}\end{array}$ \\
\hline $4 \mathrm{C}$ & & & & & 77.4 & $3.65, \mathrm{~m}$ \\
\hline $5 \mathrm{C}$ & & & & & $67.0 \mathrm{CH}$ & $4.09, \mathrm{~m}$ \\
\hline $6 \mathrm{C}$ & & & & & $17.5 \mathrm{CH}_{3}$ & $1.10, \mathrm{~d}(6.6)$ \\
\hline \multicolumn{7}{|c|}{ Sugar D, $\alpha$-L-aculose } \\
\hline $1 \mathrm{D}$ & & & & & $96.0 \mathrm{CH}$ & $5.31, \mathrm{~d}(3.5)$ \\
\hline $2 \mathrm{D}$ & & & & & $145.2 \mathrm{CH}$ & $7.03, \mathrm{dd}(10.2,3.5)$ \\
\hline $3 \mathrm{D}$ & & & & & $127.2 \mathrm{CH}$ & $6.02, \mathrm{~d}(10.2)$ \\
\hline $4 \mathrm{D}$ & & & & & $197.3 \mathrm{C}$ & - \\
\hline $5 \mathrm{D}$ & & & & & $71.0 \mathrm{CH}$ & $4.56, \mathrm{q}(6.8)$ \\
\hline $6 \mathrm{D}$ & & & & & $15.5 \mathrm{CH}_{3}$ & $1.27, \mathrm{~d}(6.8)$ \\
\hline
\end{tabular}

${ }^{a}$ Residual signals of solvent as reference. ${ }^{b}$ Measured in DMSO- $d_{6} .{ }^{c}$ Measured in acetone- $d_{6}$.

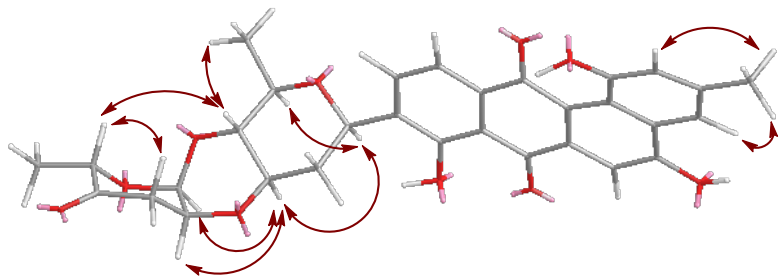

Figure 3. Key NOESY correlations for 1. 
The ${ }^{1} \mathrm{H}$ and ${ }^{13} \mathrm{C}$ NMR spectra of 1 showed that its aliphatic proton and carbon signals were very similar to those of marangucycline $B$ which has a disaccharide composed of $\beta$-D-olivose and $\alpha$-L-cinerulose B [20]. The observed COSY correlations from $\mathrm{H}-1 \mathrm{~A}\left(\delta_{\mathrm{H}} 4.97\right)$ through $\mathrm{H}-6 \mathrm{~A}\left(\delta_{\mathrm{H}}\right.$ 1.26) confirmed the presence of an olivose (Figure 2). The COSY correlations from $\mathrm{H}-1 \mathrm{~B}\left(\delta_{\mathrm{H}} 5.22\right)$ through $\mathrm{H}-3 \mathrm{~B}\left(\delta_{\mathrm{H}} 2.47,2.90\right)$, along with the $\mathrm{HMBC}$ correlations from $\mathrm{CH}_{3}-6 \mathrm{~B}\left(\delta_{\mathrm{H}} 1.24\right)$ to $\mathrm{C}-4 \mathrm{~B}\left(\delta_{\mathrm{C}}\right.$ 208.7) and $\mathrm{C}-5 \mathrm{~B}\left(\delta_{\mathrm{C}} 76.9\right), \mathrm{H}-1 \mathrm{~B}\left(\delta_{\mathrm{H}} 5.22\right)$ to $\mathrm{C}-5 \mathrm{~B}\left(\delta_{\mathrm{C}} 76.9\right)$, and $\mathrm{H}-2 \mathrm{~B}\left(\delta_{\mathrm{H}} 4.34\right)$ to $\mathrm{C}-4 \mathrm{~B}\left(\delta_{\mathrm{C}} 208.7\right)$ confirmed the structure of cinerulose $\mathrm{B}$. The linkage of two deoxy sugars was deduced by the HMBC correlations from $\mathrm{H}-1 \mathrm{~B}$ to $\mathrm{C}-4 \mathrm{~A}$, and the NOESY correlation between $\mathrm{H}-2 \mathrm{~B}$ to $\mathrm{H}-3 \mathrm{~A}$ in the most stable conformation obtained by optimizing the molecule to minimized energy by MM2 in ChemBio3D Ultra 14.0 software (Figure 3). The relative configurations of both deoxy sugars were identified as $\beta$-D-olivose and $\alpha$-L-cinerulose $B$, respectively, by NOESY correlations $\mathrm{H}-1 \mathrm{~A} / \mathrm{H}-5 \mathrm{~A}, 3 \mathrm{~A}, \mathrm{H}-3 \mathrm{~A} / \mathrm{H}-1 \mathrm{~B}, 2 \mathrm{~B}$, and $\mathrm{H}-4 \mathrm{~A} / \mathrm{H}-6 \mathrm{~A}, 5 \mathrm{~B}$ (Figure 3). Based on the HMBC correlations from $\mathrm{H}-1 \mathrm{~A}$ to $\mathrm{C}-8, \mathrm{H}-1 \mathrm{~A}$ to $\mathrm{C}-9$ and $\mathrm{H}-1 \mathrm{~A}$ to $\mathrm{C}-10$, this disaccharide was linked to the aglycone at $\mathrm{C}-9$ through $\mathrm{C}-1$ of $\beta$-D-olivose moiety. Thus, the structure of $\mathbf{1}$ was established and named as landomycin $\mathrm{N}$ according to the structural classification code of angucycline initially proposed by Rohr et al. [1] (Figure 1).

Galtamycin C (2) is an isomer of $\mathbf{1}$, due to its HRESIMS data $m / z 561.1752[\mathrm{M}+\mathrm{H}]^{+}$(calcd for $\left.\mathrm{C}_{31} \mathrm{H}_{29} \mathrm{O}_{10}, 561.1761\right)$. The ${ }^{1} \mathrm{H}$ and ${ }^{13} \mathrm{C}$ NMR spectra showed that its aliphatic proton and carbon signals were similar to those of 1 , suggesting the presence of the disaccharide $\alpha$-L-cinerulose B- $(1 \rightarrow 4$, $2 \rightarrow 3$ )- $\beta$-D-olivosyl moiety (Table 1 ). The ${ }^{1} \mathrm{H}$ NMR of 2 also showed five aromatic proton signals at $\delta_{\mathrm{H}} 8.39(\mathrm{~s}), 7.87(\mathrm{~d}, J=7.8 \mathrm{~Hz}), 7.73(\mathrm{~d}, J=7.8 \mathrm{~Hz}), 7.52(\mathrm{brs})$ and $6.95(\mathrm{brs})$, where the singlet at $\delta_{\mathrm{H}}$ 8.39 (s) has higher frequency than the corresponding singlet of $\mathbf{1}$. The ${ }^{13} \mathrm{C}$ NMR spectrum (Table 1 ) dispalyed sixteen aromatic carbons with chemical shifts ranging from $\delta_{C} 108.8$ to 162.1 and two quinone carbonyl carbons at $\delta_{C} 187.3$ and 186.3 were similar to those of rearranged linear angucycline glycosides, galtamycinone, grincamycin and grincamycin $\mathrm{H}[7,21]$. Hence, 2 was suggested to possess a linear tetracyclic system. The structure of the compound and the relative configurations of the two deoxysugars were confirmed by COSY, HMBC and NOESY correlations (Figures 2 and 4). Therefore, 2 was named galtamycin C (Figure 1).
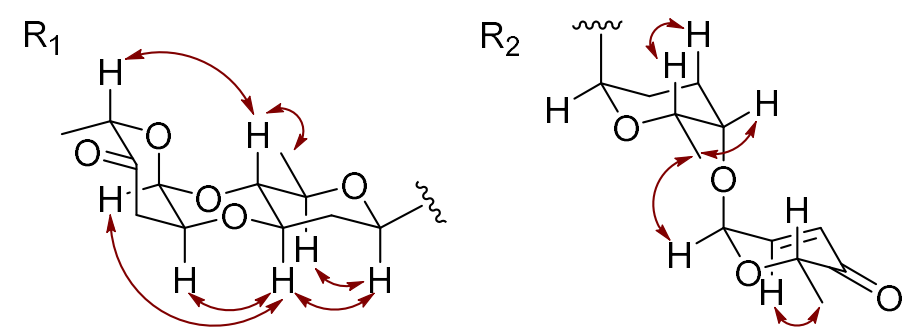

Figure 4. Key NOESY correlations in the sugar moiety of $\mathbf{2}$ and $\mathbf{3}$.

Vineomycin D (3) was isolated as a yellow powder. Its HR-ESI-MS displayed the quasimolecular ion at $m / z 838.3292\left(\left[\mathrm{M}+\mathrm{NH}_{4}\right]^{+}\right.$, calcd for $\left.\mathrm{C}_{43} \mathrm{H}_{52} \mathrm{NO}_{16}, 838.3286\right)$ and $m / z 843.2838\left([\mathrm{M}+\mathrm{Na}]^{+}\right.$, calcd for $\left.\mathrm{C}_{43} \mathrm{H}_{48} \mathrm{NaO}_{16}, 843.2840\right)$, indicating the same molecular formula $\left(\mathrm{C}_{43} \mathrm{H}_{48} \mathrm{O}_{16}\right)$ as saquayamycin B (4). Similar to that of saquayamycin $B$, the ${ }^{1} \mathrm{H}$ NMR of 3 also showed two pairs of coupling protons signals at $\delta_{\mathrm{H}} 7.94(\mathrm{~d}, J=7.8 \mathrm{~Hz}, \mathrm{H}-10)$ and $7.80(\mathrm{~d}, J=7.8 \mathrm{~Hz}, \mathrm{H}-11)$, and $\delta_{\mathrm{H}}$ $7.84(\mathrm{~d}, J=7.8 \mathrm{~Hz}, \mathrm{H}-5)$ and $7.75(\mathrm{~d}, J=7.8 \mathrm{~Hz}, \mathrm{H}-6)$, along with a pair of olefinic protons signals of $\alpha, \beta$-conjugated carbonyl group at $\delta_{\mathrm{H}} 7.03(\mathrm{dd}, J=10.2,3.5 \mathrm{~Hz}, \mathrm{H}-2 \mathrm{D})$ and $6.02(\mathrm{~d}, J=10.2 \mathrm{~Hz}, \mathrm{H}-3 \mathrm{D})$ (Table 1). The ${ }^{1} \mathrm{H}$ and ${ }^{13} \mathrm{C}$ NMR spectra also revealed the presence of three O-glycosidic anomeric proton and carbon signals at $\delta_{\mathrm{H}} 5.31(\mathrm{~d}, J=3.5 \mathrm{~Hz}) / \delta_{\mathrm{C}} 96.0(\mathrm{CH}-1 \mathrm{D}), \delta_{\mathrm{H}} 5.26(\mathrm{~d}, J=2.8 \mathrm{~Hz}) / \delta_{\mathrm{C}} 92.2$ $(\mathrm{CH}-1 \mathrm{~B})$, and $\delta_{\mathrm{H}} 5.20(\mathrm{brs}) / \delta_{\mathrm{C}} 92.0(\mathrm{CH}-1 \mathrm{C})$, and one $\mathrm{C}$-glycosidic anomeric proton and carbon signals at $\delta_{\mathrm{H}} 5.01(\mathrm{brd}, J=10.9 \mathrm{~Hz}) / \delta_{\mathrm{C}} 72.1(\mathrm{CH}-1 \mathrm{~A})$. The most obvious difference in ${ }^{13} \mathrm{C}$ NMR spectra of 3 and 4 is the absence of a signal above $\delta_{C} 200$ in 3 , and the presence of a signal at $\delta_{C} 172.2$, characteristic of a carboxylic acid or ester group. Accordingly, 3 was suggested to have a tricyclic system with a side chain, probaly due to the opening of the cyclohexanone ring of saquayamycin B $(4)[6,7,22]$. 
The skeleton of anthraquinone and the positions of two hydroxyl groups at C-8 and C-12b were confirmed by the HMBC correlations associated with the two pairs of aromatic protons. In HMBC spectrum, the correlations from $\delta_{\mathrm{H}} 7.94(\mathrm{H}-10)$ to $\mathrm{C}-8\left(\delta_{\mathrm{C}} 159.6\right)$ and $\mathrm{C}-11 \mathrm{a}\left(\delta_{\mathrm{C}} 133.0\right), \delta_{\mathrm{H}} 7.80(\mathrm{H}-11)$ to $\mathrm{C}-7 \mathrm{a}\left(\delta_{\mathrm{C}} 116.3\right), \mathrm{C}-9\left(\delta_{\mathrm{C}} 138.8\right)$ and $\mathrm{C}-12\left(\delta_{\mathrm{C}} 189.2\right), \delta_{\mathrm{H}} 7.84(\mathrm{H}-5)$ to $\mathrm{C}-6 \mathrm{a}\left(\delta_{\mathrm{C}} 132.5\right)$ and $\mathrm{C}-12 \mathrm{~b}\left(\delta_{\mathrm{C}}\right.$ $162.4), \delta_{H} 7.75(\mathrm{H}-6)$ to $C-4 a\left(\delta_{C} 136.4\right), C-7\left(\delta_{C} 189.1\right)$ and $C-12 a\left(\delta_{C} 116.4\right)$ were observed (Figure 2$)$. The correlations from the methyl protons at $\delta_{\mathrm{H}} 1.43(\mathrm{H}-13)$ to $\mathrm{C}-2\left(\delta_{\mathrm{C}} 44.6\right), \mathrm{C}-3\left(\delta_{\mathrm{C}} 78.0\right)$ and $\mathrm{C}-4\left(\delta_{\mathrm{C}}\right.$ 39.0 ), along with the correlations from the methylene protons appearing as a couple of $A B$ system at $\delta_{H}$ 2.72 and $2.63(\mathrm{H}-2)$ to $\mathrm{C}-1\left(\delta_{\mathrm{C}} 172.1\right)$, confirmed the side chain. The linkage between the anthraquinone and side chain was deduced to be at C-4a by the HMBC correlations from methylene protons at $\delta_{\mathrm{H}} 3.23$ and $3.19(\mathrm{H}-4)$ to $C-4 a\left(\delta_{C} 136.4\right), C-5\left(\delta_{C} 140.9\right)$ and $C-12 b\left(\delta_{C} 162.4\right)$. The presence of two disaccharides $\alpha$-L-cinerulose B-( $1 \rightarrow 4,2 \rightarrow 3)-\beta$-D-olivosyl and $\alpha$-L-aculose- $(1 \rightarrow 4)-\alpha$-L-rhodinosyl groups were further deduced by COSY, HMBC and NOESY correlations (Figures 2 and 4). The HMBC correlations from $\mathrm{H}-1 \mathrm{~A}\left(\delta_{\mathrm{H}} 5.01\right)$ to $\mathrm{C}-8\left(\delta_{\mathrm{C}} 159.6\right), \mathrm{C}-9\left(\delta_{\mathrm{C}} 138.2\right)$ and $\mathrm{C}-10\left(\delta_{\mathrm{C}} 134.3\right)$ suggested that the $\alpha$-L-cinerulose B- $(1 \rightarrow 4,2 \rightarrow 3)-\beta$-D-olivosyl group was linked to C-9 through C- 1 of D-olivose moiety. The HMBC correlation from H-3A $\left(\delta_{\mathrm{H}} 5.20\right)$ to $\mathrm{C}-3\left(\delta_{\mathrm{C}} 78.0\right)$ indicated that $\alpha$-L-aculose- $(1 \rightarrow 4)-\alpha$-L-rhodinosyl group was linked to $\mathrm{C}-3$. In general, tricyclic angucyclines are derived from typical angucyclines with the same tetracyclic core structure under acidic conditions [1]. Accordingly, the absolute configuration of $C-3$ is proposed to be same as that of saquayamycin B (4) and other tricyclic angucyclines, e.g., grincamycin $B$, vineomycin $B_{2}$ and fridamycin $D[6,7,22]$. Thus, the structure of 3 was established and named vineomycin $\mathrm{D}$ (Figure 1 ).

A few anguclines, such as saquayamycin $B$, landomycin $E$, vineomycin $A_{1}$ etc., have been reported to exhibit remarkable antitumor activity against a series of tumor cell lines $[3,7,10]$. Though, the distinct in vivo toxicity restricted the further development of these compounds to be clinical drugs. Recently, an atypical angucycline, lomaiviticin A, was reported to be under preclinical evaluation for antitumor treatment due to its prominent cytotoxicity and effects of inducing double-strand breaks in DNA $[14,23]$. In present work, 1-4 were assayed for their cytotoxic activity against normal liver cell $\mathrm{LO}_{2}$, hepatoma carcinoma HepG-2, SMMC-7721 and plc-prf-5 cell lines by 3-(4,5-dimethylthiazol-2-yl)-2,5-diphenyltetrazolium bromide (MTT) method (Table 2). At the concentrations of $40 \mu \mathrm{M}, 1-3$ displayed no cytotoxicity against any of the tested cell lines. Saquayamycin B (4) displyed potent cytotoxic activity against HepG-2, SMMC-7721 and plc-prf-5 cells, with $\mathrm{IC}_{50}$ values $0.135,0.033$ and $0.244 \mu \mathrm{M}$, respectively, which are less than the $\mathrm{IC}_{50}$ of doxorubicin. Treatment of SMMC-7721 cells with saquayamycin B at concentrations ranging from 0.025 to $0.100 \mu \mathrm{M}$ for $24 \mathrm{~h}$, SMMC-7721 cells resulted in chromatin dispersion and formation of apoptotic body in DAPI staining test (Figure 5a). The apoptotic ratio of SMMC-7721 cells was dependent on the concentrations of saquayamycin B (Figure $5 b$ ).

Table 2. Cytotoxicity of $\mathbf{1}-\mathbf{4}$ against $\mathrm{LO}_{2}, \mathrm{HepG}-2$, SMMC-7721 and plc-prf-5 cells $\left(\mathrm{IC}_{50}, \mu \mathrm{M}\right)$.

\begin{tabular}{ccccc}
\hline \multirow{2}{*}{ Compounds } & \multicolumn{4}{c}{ Cell Lines } \\
\cline { 2 - 5 } & LO $_{\mathbf{2}}$ & HepG-2 & SMMC-7721 & plc-prf-5 \\
\hline $\mathbf{1}$ & $>40$ & $>40$ & $>40$ & $>40$ \\
$\mathbf{2}$ & $>40$ & $>40$ & $>40$ & $>40$ \\
$\mathbf{3}$ & $>40$ & $>40$ & $>40$ & $>40$ \\
$\mathbf{4}$ & $0.343 \pm 0.081$ & $0.135 \pm 0.056$ & $0.033 \pm 0.005$ & $0.244 \pm 0.001$ \\
Doxorubicin & $2.26 \pm 0.16$ & $0.919 \pm 0.599$ & $0.706 \pm 0.004$ & $1.03 \pm 0.99$ \\
\hline
\end{tabular}




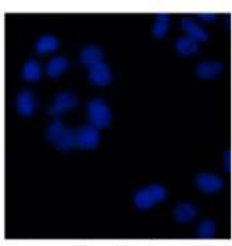

Control

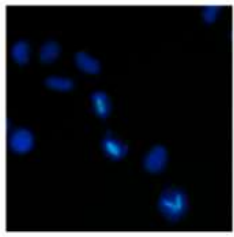

$50 \mathrm{nmol} / \mathrm{L}$

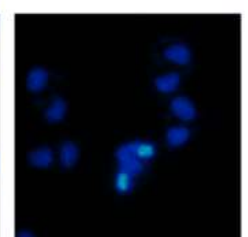

$25 \mathrm{nmol} / \mathrm{L}$

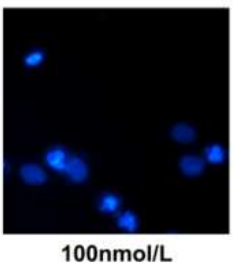

(a)

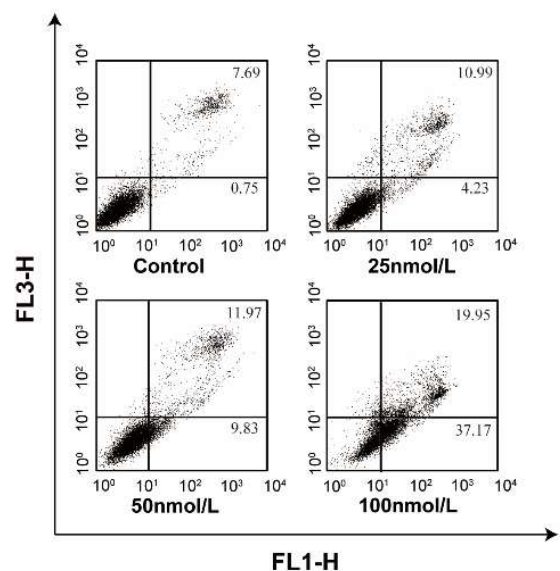

(b)

Figure 5. (a) Fluorescence micrographs of untreated and saquayamycin B-treated SMMC-7721 cells (24 h) stained with DAPI, Magnification: $100 \times$; (b) Quantification of saquayamycin B-induced apoptosis in SMMC-7721 cell using flow cytometric analysis. ${ }^{* *} p<0.01$ versus saquayamycin B $0 \mu \mathrm{M}$ group.

\section{Materials and Methods}

\subsection{General Experimental Procedures}

Optical rotations were measured with an Anton Paar MCP 200 polarimeter with a sodium lamp (589 nm) (Anton Paar GmbH, Graz, Austria). UV spectra were obtained on Genesys 10S UV-Vis spectrometer (Thermo Fisher Scientific Ltd, Waltham, MA, USA); IR spectra were recorded with a Nicolet IS5 FT-IR spectrometer (Thermo Fisher Scientific Ltd, Waltham, MA, USA); NMR spectra were recorded on Bruker AVANCE III 500 spectrometer (Bruker Inc., Karlsruhe, Germany). HPLC-MS were acquired on Agilent 1200HPLC/6520QTOFMS (Agilent Technologies Inc., Santa Clara, CA, USA). Semi-preparative HPLC isolation was performed on Agilent 1260 Infinity II (Agilent Technologies Inc., Santa Clara, USA) with an ODS column (YMC-Triart C18, $10 \mathrm{~mm} \times 250 \mathrm{~mm}$, YMC Co. Ltd., Tokyo, Japan). Silica gel (200-300 and 300-400 mesh) used in column chromatography (CC) and silica gel $\mathrm{GF}_{254}(10-40 \mu \mathrm{m})$ used in thin layer chromatography (TLC) were supplied by Qingdao Marine Chemical Factory in China.

\subsection{Actinomycetes Strain}

The intertidal sediment was collected after the tide has ebbed in Xiaoshi Island, Weihai, China in September 2016. The strain OC1610.4 was isolated from this sediment using Gause's synthetic medium $\left(20 \mathrm{~g} / \mathrm{L}\right.$ amylogen, $1 \mathrm{~g} / \mathrm{L} \mathrm{KNO} 3,0.5 \mathrm{~g} / \mathrm{L} \mathrm{NaCl}, 0.5 \mathrm{~g} / \mathrm{L} \mathrm{K}_{2} \mathrm{HPO}_{4} \cdot \mathrm{H}_{2} \mathrm{O}, 0.5 \mathrm{~g} / \mathrm{L} \mathrm{MgSO}{ }_{4} \cdot \mathrm{H}_{2} \mathrm{O}$, $0.01 \mathrm{~g} / \mathrm{L} \mathrm{FeSO}_{4} \cdot \mathrm{H}_{2} \mathrm{O}$, and $3.0 \%$ sea salt $)$ containing potassium dichromate $(6 \mu \mathrm{g} / \mathrm{mL})$ and nalidixic acid $(20 \mu \mathrm{g} / \mathrm{mL})$ as antifungal and antibacterial agents. The procedures of DNA extraction and PCR amplification of 16S rRNA were same as described in reference [24]. The nucleotide sequence of the OC1610.4 strain was sequenced at the Shanghai Sangon Biotech Co., China, and deposited at GenBank (Accession no. MK045847). Voucher strain (No. OC1610.4) was deposited at Laboratory of Natural Products Chemistry, Department of Pharmacy, Shandong University at Weihai.

\subsection{Fermentation, Extraction and Isolation}

The spore and mycelia suspension of strain OC1610.4 was inoculated in Erlenmeyer flasks ( $500 \mathrm{~mL}$ ) each of which contains $100 \mathrm{~mL}$ S-medium $\left(10 \mathrm{~g} / \mathrm{L}\right.$ glucose, $4 \mathrm{~g} / \mathrm{L}$ yeast extract, $4 \mathrm{~g} / \mathrm{L} \mathrm{K}_{2} \mathrm{HPO}_{4}, 2 \mathrm{~g} / \mathrm{L}$ $\mathrm{KH}_{2} \mathrm{PO}_{4}, 0.5 \mathrm{~g} / \mathrm{L} \mathrm{MgSO}_{4} \cdot 7 \mathrm{H}_{2} \mathrm{O}$, and $3.0 \%$ sea salt). Total $30 \mathrm{~L}$ medium was shaking-cultured at $140 \mathrm{rpm}$ and $28^{\circ} \mathrm{C}$ for 9 days. The fermentation broth including mycelia was extracted with equal volume of EtOAc five times to give $4.6 \mathrm{~g}$ crude extract. The extract was subjected to silica gel CC (60 $\mathrm{g}, 200-300 \mathrm{mesh})$ eluting with n-hexane-acetone (10:1, 5:1, 2:1 and acetone) to give four fractions 
$\mathrm{F}_{1}-\mathrm{F}_{4}$. Part $(72 \mathrm{mg})$ of fraction $\mathrm{F}_{1}$ (n-hexane-acetone 10:1) was isolated by semi-preparative HPLC eluting with $\mathrm{CH}_{3} \mathrm{OH}-\mathrm{H}_{2} \mathrm{O}(70: 30, v / v)$ to give $5\left(5.6 \mathrm{mg}\right.$ ). Fraction $\mathrm{F}_{2}$ (n-hexane-acetone 5:1, $267 \mathrm{mg}$ ) was further purified by silica gel CC ( $1 \mathrm{~g}, 300-400$ mesh) eluting with n-hexane-acetone (10:1) to give sub-fractions $\mathrm{F}_{2 a}$ and $\mathrm{F}_{2 \mathrm{~b}}$. Sub-fractions $\mathrm{F}_{2 \mathrm{a}}(67 \mathrm{mg})$ was purified by semi-preparative HPLC eluting with $\mathrm{CH}_{3} \mathrm{OH}-\mathrm{H}_{2} \mathrm{O}(38: 62, v / v)$ to give $6(4.6 \mathrm{mg})$. The sub-fractions $\mathrm{F}_{2 \mathrm{~b}}(26 \mathrm{mg})$ was a mixture presenting two brown spots on TLC, and was isolated by semi-preparative HPLC eluting with $\mathrm{CH}_{3} \mathrm{CN}-\mathrm{H}_{2} \mathrm{O}(70: 30, v / v)$ to give $\mathbf{1}(4.2 \mathrm{mg})$ and $\mathbf{2}(3.4 \mathrm{mg})$. Fraction $\mathrm{F}_{3}$ (n-hexane-acetone 2:1, $670 \mathrm{mg}$ ) was subjected to a silica gel CC (10 g, 200-300 mesh) eluting with $\mathrm{CH}_{3} \mathrm{Cl}_{-} \mathrm{CH}_{3} \mathrm{OH}$ (20:1) to give two subfractions $\mathrm{F}_{3 \mathrm{a}}$ and $\mathrm{F}_{3 \mathrm{~b}}$. From $\mathrm{F}_{3 \mathrm{a}}(220 \mathrm{mg})$, compound $4(18 \mathrm{mg})$ was purified using a low pressure silica gel CC ( $1 \mathrm{~g}$, 300-400 mesh) eluting with n-hexane-acetone (4:1). Subfractions $\mathrm{F}_{3 \mathrm{~b}}(67 \mathrm{mg})$ was isolated by semi-preparative HPLC eluting with $\mathrm{CH}_{3} \mathrm{CN}-\mathrm{H}_{2} \mathrm{O}(65: 35, v / v)$ to give $3(5 \mathrm{mg})$.

Landomycin N (1): brown amorphous powder; $[\alpha]_{\mathrm{D}}^{25}+92$ (c 0.002, MeOH); UV (MeOH) $\lambda_{\max }(\log$ ع) 225 (2.99), 327 (2.65) nm; IR (KBr) $v_{\max }$ 3203, 2974, 2916, 1726, 1629, 1607, 1578, 1433, 1295, 1111, $1075,852,791 \mathrm{~cm}^{-1} ;{ }^{1} \mathrm{H}$ NMR (500 MHz, DMSO- $\left.d_{6}\right)$ and ${ }^{13} \mathrm{C}$ NMR (125 MHz, DMSO- $\left.d_{6}\right)$ data, Table 1; HR-ESI-MS $m / z 561.1753\left([\mathrm{M}+\mathrm{H}]^{+}\right.$, calcd for $\left.\mathrm{C}_{31} \mathrm{H}_{29} \mathrm{O}_{10}, 561.1761\right)$.

Galtamycin C (2): reddish-brown amorphous powder; $[\alpha]_{\mathrm{D}}^{25}+285(c 0.003, \mathrm{MeOH}) ; \mathrm{UV}(\mathrm{MeOH}) \lambda_{\max }$ ( $\log \varepsilon) 265$ (2.40), 340 (2.07) nm; IR (KBr) $v_{\max }$ 3383, 2917, 2879, 1727, 1657, 1608, 1584, 1525, 1471, $1286,1247,1108,1017,872,836,716 \mathrm{~cm}^{-1} ;{ }^{1} \mathrm{H}$ NMR (500 MHz, DMSO- $\left.d_{6}\right)$ and ${ }^{13} \mathrm{C}$ NMR $(125 \mathrm{MHz}$, DMSO- $d_{6}$ ) data, Table 1 ; HR-ESI-MS $m / z 561.1752\left([\mathrm{M}+\mathrm{H}]^{+}\right.$, calcd for $\left.\mathrm{C}_{31} \mathrm{H}_{29} \mathrm{O}_{10}, 561.1761\right)$.

Vineomycin D (3): yellow amorphous powder; $[\alpha]_{\mathrm{D}}^{25}+69$ (c 0.050, MeOH); $\mathrm{UV}(\mathrm{MeOH}) \lambda_{\max }(\log \varepsilon) 230$ (3.56), 259 (3.28), 295 (2.83) nm; IR (KBr) $v_{\max }$ 3557, 2978, 2935, 1731, 1702, 1625, 1581, 1431, 1259, 1080, $1014,899,808 \mathrm{~cm}^{-1} ;{ }^{1} \mathrm{H}$ NMR (500 MHz, acetone- $\left.d_{6}\right)$ and ${ }^{13} \mathrm{C}$ NMR $\left(125 \mathrm{MHz}\right.$, acetone- $\left.d_{6}\right)$ data, Table 1 ; HR-ESI-MS $m / z 838.3292\left(\left[\mathrm{M}+\mathrm{NH}_{4}\right]^{+}\right.$, calcd for $\left.\mathrm{C}_{43} \mathrm{H}_{52} \mathrm{NO}_{16}, 838.3286\right)$ and $m / z 843.2838\left([\mathrm{M}+\mathrm{Na}]^{+}\right.$, calcd for $\mathrm{C}_{43} \mathrm{H}_{48} \mathrm{NaO}_{16}, 843.2840$ ).

\subsection{Cytotoxicity Assays, DAPI Staining Test and Flow Cytometric Analysis}

The cytotoxicity evaluations of 1-4 against normal liver cell and hepatoma carcinoma cells were carried out using the 3-(4,5-dimethylthiazole-2-yl)-2,5-diphenyltetrazolium bromide (MTT) assay. Doxorubicin was used as positive control drug and deionized $\mathrm{H}_{2} \mathrm{O}$ with the same DMSO concentration was used as parallel control. DAPI staining test was employed to qualitatively observe apoptosis, and the apoptotic ratio was measured by flow cytometric analysis (Becton Dickinson FACScan, San Jose, CA, USA). These tests were conducted using the methods as previously described $[25,26]$.

\section{Conclusions}

Four angucycline glycosides including landomycin N (1), galtamycin C (2), vineomycin D (3) and saquayamycin (4), along with two alkaloids 1 -acetyl- $\beta$-carboline (5) and indole-3-acetic acid (6), were isolated from the fermentation broth of strain Streptomyces sp. OC1610.4, obtained from the intertidal sediment. Galtamycin C (2) and vineomycin D (3) are rearranged angucycline derivatives respectively possessing a linear tetracyclic and a tricyclic framework of angucycline. Vineomycin $\mathrm{D}$ (3) and saquayamycin B (4) are isomers, comprising the same two disaccharides in the structures. Among the isolated angucycline glycosides, saquayamycin B (4) displayed the most potent cytotoxic activity against hepatoma carcinoma HepG-2, SMMC-7721 and plc-prf-5 cells. Although saquayamycin $\mathrm{B}$ was shown to induce an apoptosis in SMMC-7721 cell, its antineoplastic mechanism needs to be further investigated.

Supplementary Materials: The following are available online at http://www.mdpi.com/1660-3397/16/12/ 470/s1: This section includes the HR-ESI-MS, 1D and 2D NMR spectra for compounds 1-4. Figures S1-S8: HR-ESI-MS, 1D and 2D NMR spectra of saquayamycin B (4); Figures S9-S15: HR-ESI-MS, 1D and 2D NMR spectra of landomycin N (1); Figures S16-S22: HR-ESI-MS, 1D and 2D NMR spectra of galtamycin C (2); Figures S23-S29: HR-ESI-MS, 1D and 2D NMR spectra of vineomycin D (3). 
Author Contributions: A.P. conducted the main experiments, including the isolation and culture of strain, the isolation and structural elucidation of compounds. X.Q performed the large-scale fermentation. F.L. conducted the antitumor assay. X.L. guided the antitumor assay. E.L. guided the HPLC isolation and NMR measurement. W.X supervised the whole work and wrote the manuscript. All authors have read the manuscript and approved the final manuscript for submission.

Funding: This research was funded by the Natural Science Foundation of Shandong Province, China (ZR2014HM018) and National Natural Science Foundation of China (81872771).

Acknowledgments: We are grateful to Hong-Bo Zheng from Key Laboratory of Chemical Biology (Ministry of Education), School of Pharmaceutical Science, Shandong University, Jinan 250012, China, for recording HR-ESI-MS.

Conflicts of Interest: The authors declare no conflict of interest.

\section{References}

1. Rohr, J.; Thiericke, R. Angucycline group antibiotics. Nat. Prod. Rep. 1992, 9, 103-137. [CrossRef] [PubMed]

2. Kharel, M.K.; Pahari, P.; Shepherd, M.D.; Tibrewal, N.; Nybo, S.E.; Shaaban, K.A.; Rohr, J. Angucyclines: biosynthesis, mode-of-action, new natural products, and synthesis. Nat. Prod. Rep. 2012, 29, $264-325$. [CrossRef] [PubMed]

3. Shaaban, K.A.; Ahmed, T.A.; Leggas, M.; Rohr, J. Saquayamycins G-K, cytotoxic angucyclines from Streptomyces sp. including two analogues bearing the aminosugar rednose. J. Nat. Prod. 2012, 75, 1383-1392. [CrossRef] [PubMed]

4. Gui, C.; Liu, Y.N.; Zhou, Z.B.; Zhang, S.W.; Hu, Y.F.; Gu, Y.C.; Huang, H.B.; Ju, J.H. Angucycline glycosides from mangrove-derived Streptomyces diastaticus subsp. SCSIO GJ056. Mar. Drugs 2018, 16, 185. [CrossRef] [PubMed]

5. Erb, A.; Luzhetskyy, A.; Hardter, U.; Bechthold, A. Cloning and sequencing of the biosynthetic gene cluster for saquayamycin $\mathrm{Z}$ and galtamycin $\mathrm{B}$ and the elucidation of the assembly of their saccharide chains. ChemBioChem 2009, 10, 1392-1401. [CrossRef] [PubMed]

6. Huang, H.B.; Yang, T.T.; Ren, X.M.; Liu, J.; Song, Y.X.; Sun, A.J.; Ma, J.Y.; Wang, B.; Zhang, Y.; Huang, C.G.; et al. Cytotoxic angucycline class glycosides from the deep sea actinomycete Streptomyces lusitanus SCSIO LR32. J. Nat. Prod. 2012, 75, 202-208. [CrossRef] [PubMed]

7. Zhu, X.C.; Duan, Y.W.; Cui, Z.M.; Wang, Z.; Li, Z.X.; Zhang, Y.; Ju, J.H.; Huang, H.B. Cytotoxic rearranged angucycline glycosides from deep sea-derived Streptomyces lusitanus SCSIO LR32. J. Antibiot. 2017, 70, 819-822. [CrossRef] [PubMed]

8. Helaly, S.E.; Goodfellow, M.; Zinecker, H.; Imhoff, J.F.; Sussmuth, R.D.; Fiedler, H.P. Warkmycin, a novel angucycline antibiotic produced by Streptomyces sp. Acta 2930. J. Antibiot. 2013, 66, 669-674. [CrossRef] [PubMed]

9. Nakagawa, K.; Hara, C.; Tokuyama, S.; Takada, K.; Imamura, N. Saprolmycins A-E, new angucycline antibiotics active against Saprolegnia parasitica. J. Antibiot. 2012, 65, 599-607. [CrossRef] [PubMed]

10. Panchuk, R.R.; Lehka, L.V.; Terenzi, A.; Matselyukh, B.P.; Rohr, J.; Jha, A.K.; Downey, T.; Kril, I.J.; Herbacek, I.; van Schoonhoven, S.; et al. Rapid generation of hydrogen peroxide contributes to the complex cell death induction by the angucycline antibiotic landomycin E. Free Radical Bio. Med. 2017, 106, 134-147. [CrossRef] [PubMed]

11. Korynevska, A.; Heffeter, P.; Matselyukh, B.; Elbling, L.; Micksche, M.; Stoika, R.; Berger, W. Mechanisms underlying the anticancer activities of the angucycline landomycin E. Biochem. Pharmacol. 2007, 74, 1713-1726. [CrossRef] [PubMed]

12. Fidan, O.; Yan, R.M.; Gladstone, G.; Zhou, T.; Zhu, D.; Zhan, J.X. New insights into the glycosylation steps in the biosynthesis of Sch47554 and Sch47555. ChemBioChem 2018, 19, 1424-1432. [CrossRef] [PubMed]

13. Salem, S.M.; Weidenbach, S.; Rohr, J. Two cooperative glycosyltransferases are responsible for the sugar diversity of saquayamycins isolated from Streptomyces sp. KY 40-1. Acs Chem. Biol. 2017, 12, 2529-2534. [CrossRef] [PubMed]

14. Huang, C.S.; Yang, C.F.; Zhang, W.J.; Zhang, L.P.; De, B.C.; Zhu, Y.G.; Jiang, X.D.; Fang, C.Y.; Zhang, Q.B.; Yuan, C.S.; Liu, H.W.; Zhang, C.S. Molecular basis of dimer formation during the biosynthesis of benzofluorene-containing atypical angucyclines. Nat. Commun. 2018, 9, 2088. [CrossRef] [PubMed]

15. Jose, P.A.; Jha, B. Intertidal marine sediment harbours Actinobacteria with promising bioactive and biosynthetic potential. Sci. Rep. 2017, 7, 10041. [CrossRef] [PubMed] 
16. Zhou, T.S.; Ye, W.C.; Wang, Z.T.; Che, C.T.; Zhou, R.H.; Xu, G.J.; Xu, L.S. $\beta$-Carboline alkaloids from Hypodematium squamuloso-pilosum. Phytochemistry 1998, 49, 1807-1809. [CrossRef]

17. Han, X.; Hou, L.K.; Hou, J.; Zhang, Y.Y.; Li, H.Y.; Li, W.L. Heterologous expression of a VioA variant activates cryptic compounds in a marine-derived Brevibacterium strain. Mar. Drugs 2018, 16, 191. [CrossRef] [PubMed]

18. Uchida, T.; Imoto, M.; Watanabe, Y.; Miura, K.; Dobashi, T.; Matsuda, N.; Sawa, T.; Naganawa, H.; Hamada, M.; Takeuchi, T.; et al. Saquayamycins, new aquayamycin-group antibiotics. J. Antibiot. 1985, 38, 1171-1181. [CrossRef] [PubMed]

19. Feng, Z.M.; He, J.; Jiang, J.S.; Chen, Z.; Yang, Y.N.; Zhang, P.C. NMR solution structure study of the representative component hydroxysafflor yellow A and other quinochalcone C-glycosides from Carthamus tinctorius. J. Nat. Prod. 2013, 76, 270-274. [CrossRef] [PubMed]

20. Song, Y.X.; Liu, G.F.; Li, J.; Huang, H.B.; Zhang, X.; Zhang, H.; Ju, J.H. Cytotoxic and antibacterial angucyclineand prodigiosin-analogues from the deep-sea derived Streptomyces sp. SCSIO 11594. Mar. Drugs 2015, 13, 1304-1316. [CrossRef] [PubMed]

21. Stroch, K.; Zeeck, A.; Antal, N.; Fiedler, H.P. Retymicin, galtamycin B, saquayamycin Z and ribofuranosyllumichrome, novel secondary metabolites from Micromonospora sp. Tu 6368-II. Structure elucidation. J. Antibiot. 2005, 58, 103-110. [CrossRef] [PubMed]

22. Maskey, R.P.; Helmke, E.; Laatsch, H. Himalomycin A and B: Isolation and structure elucidation of new fridamycin type antibiotics from a marine Streptomyces isolate. J. Antibiot. 2003, 56, 942-949. [CrossRef] [PubMed]

23. Herzon, S.B. The mechanism of action of (-)-lomaiviticin A. Accounts Chem. Res. 2017, 50, $2577-2588$. [CrossRef] [PubMed]

24. Zhang, X.M.; Liu, X.; Wang, Z.; Tian, Z.H.; Xie, W.D. Viridobrunnines A and B, antimicrobial phenoxazinone alkaloids from a soil associated Streptomyces sp. Heterocycles 2015, 91, 1809-1814.

25. Liu, S.S.; Wang, Y.F.; Ma, L.S.; Zheng, B.B.; Li, L.; Xie, W.D.; Li, X. 1-Oxoeudesm-11(13)-eno-12,8a-lactone induces $\mathrm{G}_{2} / \mathrm{M}$ arrest and apoptosis of human glioblastoma cells in vitro. Acta Pharmacol. Sin. 2013, 34, 271-281. [CrossRef] [PubMed]

26. Zheng, B.B.; Wu, L.H.; Ma, L.S.; Liu, S.S.; Li, L.; Xie, W.D.; Li, X. Telekin induces apoptosis associated with the mitochondria-mediated pathway in human hepatocellular carcinoma cells. Biol. Pharm. Bull. 2013, 36, 1118-1125. [CrossRef] [PubMed] 